International Handbook of Political Ecology (Ray Bryant ed, Edward Elgar 2015) pp. 27 - 43

\title{
Doing political ecology inside and outside the academy
}

Simon Batterbury $\quad$ University of Melbourne/Lancaster University

\begin{abstract}
The chapter presents a survey of political ecology (PE) scholarship in, and beyond, academic institutions. This interdisciplinary field makes a contribution to understanding environmental and social justice issues, that require explanations at multiple scales, often challenging powerful state and corporate actors. Radical and critical scholarship like PE survives because of sustained student demand, but in neoliberal universities battling financial shortfalls and sometimes a reluctance to invest in research areas that offer critique of powerful institutions and of injustice. Political ecologists have a substantial presence in North America and Europe, either as individual scholars or in small research clusters, but are found across the world and are networked virtually and through key events and collaborative ventures. Publishing outlets include at least three dedicated journals. The extent to which academic political ecology can, and should, make a contribution to engaged scholarship, stepping beyond the boundaries of academic investigation into the messy world of environmental politics is debated, but embraced by some academics, numerous NGOs, and civil society organizations. The future of the field is assured if environmental despoliation, denial of access to resources, and inequality continues; and if its hopes for better world are not extinguished by much more powerful actors in and outside the university system.
\end{abstract}

This chapter reflects on some practical settings in which political ecology is done inside and beyond academia. ${ }^{1}$ I survey political ecology scholarship, and the extent to which it treads its own path as a way to explain complex socio-environmental dynamics. Its particular type of interdisciplinary thinking continues to clash and merge with other approaches to understanding nature-society interactions and relationships.

After defining the field, I examine the context for political ecology work in academic institutions, including a fast-changing environment for critical scholarship. Publication outlets include several dedicated journals, and in recent years an increase in the volume of political ecology articles and other outputs. I then argue that teaching is usually an essential component of being a political ecologist, noting that the number of political ecology classes is growing. The presence of political ecology outside the academy is gaining strength too (albeit slowly), and so is its potential for alliances and academic engagement, notably with NGOs and social movements (who already have their own analytical tools and strategies for engaging in environmental politics). A logical outcome for scholars that interrogate causes of inequality and environmental injustice is personal engagement - critically and on-the-ground - potentially involving advocacy and activism.

\section{Defining the field}

The test of any framework for understanding nature-society interaction lies not in its theoretical complexity or neatness, but in its ability to understand and explain events past and present, as appraised through research, reflection and observation. Contemporary political ecology passes this test, explaining how and why humans are transforming nature. Peet and Watts (1996) traced the term back to the 1970s, when it largely referred to the study of environmental or green politics (Enzenberger, 1974). Political scientists employed it in this way, as an 'inclusive term encompassing diverse research into policy, politics and the environment.... Neither politics nor the environment operates as a dependent or independent variable; they are interdependent' (Somma, 1993: 372). Bryant (1992:13) defined political ecology as '...the attempt to understand the political sources, conditions and ramifications of environmental change'.

Meanwhile 'regional political ecology' developed in the 1980s as a multi-scale research approach, with greater links to the environmental sciences and using a unique methodology. It entered Anglo-American geography and development studies through Piers Blaikie's ground-breaking analyses of soil erosion (Blaikie, 1985) and land degradation (Blaikie, 1989b, 1991; Blaikie and Brookfield, 1987). Rejecting apolitical (or nonpolitical) explanations that tend to blame overpopulation or land user practices for land degradation, this approach uses nested analytical scales spanning 'local-level field studies and macro-level processes' (Bassett, 1988:472), and combining a rigorous political economy analysis of land degradation with social and environmental investigation. The argument is that access to environmental resources is always socially mediated or constrained, usually involving multiple processes acting at different scales. It is not a theory; rather, as Blaikie (1989a: 27) points out, it is the 'spine' of an approach to which theoretical and empirical material may be attached. Students of the Blaikie and Brookfield model have refined it and attacked it, but applied it to understanding social vulnerability to natural hazards, as well as to a loss of access to natural resources more 
broadly. It has proven particularly effective in uncovering the roots of environmental degradation and different forms of injustice.

Political ecology has proven to be a popular academic approach. Some of this has to do with the growth of environmentalism since the 1960s, responding in particular to the effects of environmental problems and injustices, many linked to globalisation and neo-liberal regimes. The threats include the real and existential, particularly from anthropogenic climate change, and a widespread failure by key actors (states, large corporations) to recognize environmental and social justice as more important than short-term profits and votes. For most political ecologists, a deep ethical commitment, sometimes but not always tied to a radical personal politics, means that what really matters to them are the constraints placed by an 'unsympathetic socio-economic milieu' (Amanor, 1994: 222) on human agency and creativity, as well as on healthy environments and biodiversity. Problems of differential and gendered resource access, land rights and indeed the wider political economy conspire to leave some people more vulnerable or 'marginalized' than others (Wisner, 1993; Wisner et al., 2004). Many aspects of how contemporary economies, cultures and ways of life operate today pose limitations on the adaptive capacities of human agents in specific localities, even as these agents struggle and fight against these broader constraints (Davies, 1996: 57).

The best research in political ecology begins with the tactics and strategies of making a living in a particular environment, while also interrogating the socio-economic milieu and the dynamics of that environment (Perramond, 2007; Tschakert, 2013). There are often complex geographical and historical dimensions to these livelihoods, prompting scholars to develop a 'chain of explanation' to understand them. Key themes have included:

(1) Access to resources. Rights to natural resources are vital for welfare and livelihood. Gender, class, ethnicity, political status and other vectors of power influence patterns of ownership and control. Resource access is a function of how production and economic accumulation strategies occur, which in turn influences differences in social relations. A large literature has formed around these 'access to resources' questions (Bassett and Crummey, 1993; Bassett, 1988; Berry, 1993; Gray and Dowd-Uribe, 2013; Rocheleau et al., 1996; Rocheleau and Edmunds, 1997; Schroeder, 1997).

(2) Struggle and resistance against forces that conspire to frustrate peoples' attempts to make a living, notably to closure of resources access and environmental 'bads'. This may occur through open forms of political organizing and protest or less visible forms of 'passive' resistance that short-changes the powerful in diverse ways (Peluso, 1992; Scott, 1985). Activists and social movements have fought for rights and justice, often ahead of the political ecologists that later adopt their ideas and concepts (Escobar, 2008; Martinez-Alier et al., 2014).

(3) Profound upheaval in local peoples' ways of life that involve social, economic and environmental change, for example '...the transformation of indigenous systems of resource management in the process of incorporation into the global economy' (Bassett, 1988:434). Scholars also assess the impact of international development programmes and associated reconfigurations of state-society relations (van der Ploeg and Long, 1994; Olivier de Sardan, 1984). The penetration of capitalist relations in the non- or less-capitalist world, and the appropriation of land and labour in this process through commodification, has been a major concern. Political ecologists also examine 'identity' and the struggle over the different worldviews and philosophies guiding humanity's relationship to nature (Escobar, 2008).

Today, scholars are also engaging with an array of old and new topical areas, notably extractive economies and the growth of mining (Adkin, forthcoming; Bebbington and Bury, 2007), international land grabs for food security, biofuel or timber (McMichael, 2014), the impact of protected areas on livelihoods (Vaccaro et al., 2013), food politics (Bryant and Goodman, 2004), and the possibilities for equitable economic de-growth under capitalism (Schneider et al., 2010). There are, too, links to the international climate change agenda, through studies of $\mathrm{CO}_{2}$ emitting culprits and local vulnerabilities to changing climates (Tschakert, 2013). Then, there is a strong political ecology of urban environmental dynamics (Lawhon et al., 2014). These and other new research areas benefit from, and contribute to, analytical and methodological pluralism in the field and across the environmental social sciences (Doolittle, this volume; Perramond, 2007; Turner, this volume).

\section{Academic political ecology}

Who does political ecology? Most of those who would classify themselves as political ecologists are based in academia. Academic political ecology is largely conducted in institutions that nowadays tolerate its radical aspirations. Toleration is undoubtedly linked to the field's popularity, as evinced by the sheer number of academic job seekers, publications in diverse formats, conferences, and undergraduate and postgraduate enrolments. 
This growing popularity occurs in a broader context of increasing academic insecurity. In the US, permanent (or tenure track) teaching and research jobs are on the decline. Meanwhile, where demand for teaching remains high, much more of it is being done by adjunct staff - a temporary labour force paid per class and often without satisfactory workspace, health cover or superannuation (Batterbury, 2008a). This process is all about saving costs during a period of unprecedented systemic stress, some driven by the lingering effects of the global financial crisis that has hit universities in Europe and North America especially hard. These pressures demand greater employee flexibility in response to the ebb and flow of student demand and funding. Critical scholars, including many political ecologists, object to neoliberal thinking which seeks to remove freedoms that interfere with the 'smooth operation' of the education marketplace (notably unions and tenure contracts). In Australia and the UK, years of politically-minded interventions have produced a more 'competitive' setting (designed to emulate the private sector) in which universities fight each other for research funding and 'rankings' - things that in turn directly influence which academics are hired or fired. Although less the case in the US, 'restructuring' processes alter departmental names and disciplinary groupings. Intellectual logic has little to do with any of this.

Not surprisingly, most political ecologists find restructuring and performance metrics to breach the basic principles of academic freedom. They hold to a tradition of radical distrust of powerful institutions that lack transparency and fairness. And, while many political ecologists are by nature somewhat flexible in the sense that they can operate in or across different academic disciplines, student 'access' to radical, politically potent and establishment-threatening ideas may be shut down. Hence, that marketplace may serve as a de facto means of intellectual censorship, closing yet another space in society for alternative thinking.

And yet as I argue elsewhere, political economy (including radical political ecology) is so entrenched in western universities that it is apparently hard to dislodge it. Indeed, some 'productive' radical scholars have even taken key institutional leadership positions (Batterbury, 2013). It is ironic that radical intellectual content is compatible with performance metrics - this marks a change from the 1960s and 1970s when scholars were fired and denied tenure in North America for espousing radical views.

How to 'perform' political ecology in such an environment? Scholars certainly need to accommodate an increasingly difficult and fragile set of institutional constraints. Most of them work in departments without many like-minded colleagues, where students take their specialist classes as optional units, and activity is generally built around disciplines. In some institutions there are clusters of individuals with similar interests, often across disciplines or departments, albeit groupings that ebb and flow over time with departures, arrivals and funding opportunities.

\section{Key clusters and academic centres}

There is a discernible if ever shifting geography to the worldwide political ecology community. ${ }^{2}$ In the US, employment in a PhD-granting program offers the possibility of gaining academic tenure, and forming a political ecology 'node' or 'cluster' with students who then perpetuate the field. The University of California, Berkeley and Clark University (in Massachusetts) have arguably produced the greatest number of PhD students connected to political ecology, working with scholars including Jake Kosek, Donald Moore, Nancy Peluso, Nathan Sayre and Michael Watts; and Doug Johnson, Dick Peet, Dianne Rocheleau, Billie Lee Turner II, Tony Bebbington and James McCarthy. Indeed, Berkeley has its own Political Ecology Research Group (https://plus.google.com/111554681451775708952). But Clark and Berkeley are certainly not alone in teaching and granting PhDs, with significant groupings of faculty and students at the public universities of Colorado (Mara Goldman, Emily Yeh), Georgia (Peter Brosius, Nik Heynen, Jennifer Rice, Julie Velásquez Runk), Illinois (Tom Bassett, Trevor Birkenholtz, Jesse Ribot), Kentucky (Shannon Bell, Lisa Cliggett, Tad Mutersbaugh, Sarah Lyon), Michigan (Arun Agrawal, Bilal Butt, Rebecca Hardin, Paul Mohai, Ivette Perfecto, Dorceta Taylor), Ohio State (Kendra McSweeney, Becky Mansfield, Joel Wainright, Anna Willow), Oregon (Derrick Hindery, Katie Meehan, Peter Walker), Penn State (Brian King, Karl Zimmerer), Rutgers (Heidi Hausermann, Rick Schroeder, Kevin St.Martin), UC Santa Cruz (Jeff Bury, Julie Guthman, Margaret Fitzsimmons, Ravi Rajan), Washington (Lucy Jarosz, and a Center for Environmental Politics), WisconsinMadison (Ian Baird, Lisa Naughton, Paul Robbins, Morgan Robertson, Matt Turner), and in the New York college system (e.g. Paige West at Barnard). The University of Arizona has Tracey Osborne's Public Political Ecology Lab (http://ppel.arizona.edu), and it is where Diana Liverman also co-directs the Institute of Environment, and anthropologists Jim Greenberg and Tad Park founded the Journal of Political Ecology in 1993 (see below). There are political ecologists at Cornell (Ron Herring, Phil McMichael, Wendy Wolford), Syracuse (Sharon Moran, Tom Perrault, Farhana Sultana) and Yale (Michael Dove and several others working across environmental studies, forestry and anthropology).

In Canada, the University of British Columbia (Philippe Le Billon, Karen Bakker, Juanita Sundberg), the University of Toronto (Michael Ekers, Tania Li, Ken MacDonald, Sharlene Mollett, Scott Prudham) and McGill (Sarah Turner, John Unruh, Ismael Vaccaro) have significant expertise. York University (Roger Keil, 
Robin Roth, Peter Vandergeest) also hosts an international political economy and ecology summer camp. In Mexico, Durand Smith et al (2011) identify a node of researchers at the Universidad Nacional Autónoma de México (UNAM) led by Enrique Leff that heralded the arrival of an 'ecología política mexicana'.

The UK also has a longstanding and vibrant community. London is one centre, with faculty notably at SOAS (Rosaleen Duffy), the LSE (Jennifer Baka, Tim Forsyth), King's College London (Raymond Bryant, Alex Loftus, Daanish Mustafa, Mark Pelling, Michael Redclift and formerly Mike Goodman now at Reading University) and University College London (Matthew Gandy, Ilan Kelman, Ben Page, Graham Woodgate). But there are important political ecology groupings elsewhere in the UK, notably at Cambridge (Bill Adams, Ivan Scales, Bhaskar Vira), Manchester (Dan Brockington; Maria Kaika, John O'Neill, Eric Swyngedouw, Phil Woodhouse), Durham (Gavin Bridge, Harriet Bulkeley), University of East Anglia (Pier Blaikie, Jessica Budds, Thomas Sikor, Oliver Springate-Baginski) and at Sussex where the work of Terry Cannon, James Fairhead, Amber Huff, Melissa Leach, Lyla Mehta, Peter Newell and Ian Scoones resonates with a political ecology approach. Lancaster University is establishing its own research and teaching, linked to an existing environmental institute.

Political ecology has also set down roots in a variety of other European countries, reflecting a complex set of historical influences and tendencies. Research in northern Europe encompasses faculty in Norway (Tor Benjaminsen), where there is a national research network on Political Ecology and Environmental Policy (http://www.ntnu.edu/political-ecology), Sweden (Henrik Ernstson, Alf Hornborg, Andrea Nightingale), Denmark (Christian Lund, Jens Friis Lund), and Finland (Anja Nygren). The approach is represented in universities in Austria (International Political Ecology research group, University of Vienna), Switzerland (Benedikt Korf, Christian Kull, René Véron, Anna Zimmer) and Germany (Thomas Krings, Marcus Nüsser and the late Hans-Georg Bohle). The Netherlands has at least one Chair in political ecology and scholars working across several major universities and disciplines (e.g. Murat Arsel, Rutgerd Boelens, Bram Büscher, Rob Fletcher, Kees Jansen, Esther Turnhout), while in Belgium, there are scholars such as Anneleen Kenis and Johan Bastiaensen.

There is also growing interest in Italy (Koensler and Papa, 2013) and Portugal (Stefania Barca; see also Freitas and Mozine, this volume), as well as in Spain, especially at the Autonomous University of Barcelona (AUB) which is at the forefront of work connecting political ecology to ecological economics (Joan Martinez-Alier, Giorgos Kallis). In France, there is a longstanding and quite unique tradition of 'écologie politique' that has 'Green' activist political connotations, and some academic connections via the work of Alain Lipietz and René Dumont (Chartier and Rodary, this volume). But a group of geographers has begun to use the label 'political ecology' (when writing in French) (Gautier and Hautdidier, this volume; Molle et al. 2009). Benchmark books (e.g. Gautier and Benjaminsen, 2012) and conferences (http://www.politicalecology.fr) have been the result.

Political ecology extends well beyond Europe and North America. In Australia, for example, the Australian National University was the prime node for environment and development research for many years, and has several faculty members while offering postgraduate degree options (Matthew Allen, Keith Barney, Kuntala Lahiri-Dutt, Sango Mahanty, John McCarthy, Sarah Milne). Faculty members broadly interested in political ecology work at universities in New South Wales (Noel Castree, John Connell, Phil Hirsch, Fiona Miller, David Schlosberg), around Brisbane (Jason Byrne, Kristen Lyons, Kim de Rijke), as well as through an informal network connecting Melbourne and Monash universities (Hans Baer, Simon Batterbury, Adam Bumpus, Brian Cook, Wolf Dressler, Lisa Palmer, Haripriya Rangan, Craig Thorburn).

In South Asia, a particular focus has been on the interconnections between environmental history and political ecology, inspired in India by literary giants like Ramachandra Guha and Madhav Gadgil who wrote expansively on the longue durée of human-environment relationships (Gadgil and Guha, 1992), as well as Mahesh Rangarajan (Director of the Nehru Memorial Museum and Library). Scholarship by Bina Agarwal (Delhi and Manchester Universities) has explored governance themes in feminist political ecology. There is also a strong tradition of interrogating peasant society, agrarian change and state-society relations, but largely from outside the continent (e.g. Arun Agrawal, 2005). Meanwhile, the Ashoka Trust for Research in Ecology and the Environment (ATREE) with its main base in Bangalore is beginning to act as a centre for Indian political ecology with Sharachchandra Lélé and others (and now awards masters and PhDs through Manipal University). Scholars based in Bangladesh (Tanzimuddin Khan), Pakistan and Nepal (Pandey, 2013) also conduct research in the field. In South-East Asia, political ecology themes appear at the National University of Singapore (Harvey Neo, C.C. Pow, Jonathan Rigg) and De La Salle University, Manila (Antonio Contreras, Marvin Montefrio). South Korea and Japan produce a literature that loosely connects to political ecology often linked to water and conservation matters (e.g. Seungho Lee, this volume; Tuk-Po et al., 2003), while in China, most scholars are still based outside the country (Yeh, this volume).

In Latin America the international character of political ecology is clearly demonstrated. Here, intellectual influences have come from inside and outside the region, featuring writing in Spanish, English and French (Chartier and Löwy, 2013; Martin and Larsimont, 2014; Leff, this volume; Freitas and Mozine, this volume). Notable is the work linked to CLACSO in Argentina with a working group concerned with power 
dynamics and nature-society relations (Hector Alimonda, 2002). Eduardo Gudynas heads a social ecology research centre in Uruguay (CLAES). Often there is a concern with past and present relations of coloniality (Alimonda, this volume; research by Andrea Zhouri on Brazil), while in Colombia the Universidad de los Andes has a group working on development and environment with connections to other regional universities. Serving as a 'bridge' between this variegated scholarship and the Anglo-American literature is the Colombianborn anthropologist Arturo Escobar (University of North Carolina) (e.g. 2008) and other western-trained political ecologists, including Diana Ojeda.

African universities have so far largely bypassed the approach with the exception of South Africa (Patrick Bond, David Fig, Mary Lawhon, Maanu Ramutsindela) (Bond, 2012; Lawhon et al., 2014; Wynberg and Fig, 2014), although scholars draw on it in Ghana (Kojo Amanor), Nigeria (Godwin Ojo) and Tanzania (Christine Noe). As this International Handbook highlights and as Kim et al. (2012) note, 'other' political ecologies signal an expansion and a shift in scholarly activity as work in the global South is expanding - driven in part by returnees from European and North American doctoral programs.

\section{Networks}

The hallmarks of a strong academic field include being open and supportive, and building bridges across academia, nonprofits and implementing agencies. Political ecologists, scattered around the world, operate through a multifaceted set of academic networks. Long before social media, the Cultural and Political Ecology Speciality Group of the Association of American Geographers played a role in hosting a Newsletter, annual awards and conference sessions, and then a listserv from the early1990s. The Santa Cruz based Center for Political Ecology dates to 1989, and was established by the Marxist academic, James O'Connor. It describes itself as a 'flexible, resilient cyber-based organization' (http://www.centerforpoliticalecology.org). It also established the journal Capitalism, Nature, Socialism and features the work of several scholars with strong activist links, including Barbara Rose Johnson. American anthropologists have the Political Ecology Society (PESO) and its listserv, as part of the Society for Applied Anthropology. Other networks include the interdisciplinary Political Ecology Working Group, established at the University of Kentucky in 2010, which organizes an annual Dimensions of Political Ecology Conference (DOPE). Its listserv, the International Political Ecology Collaboratory (IPEC) has rapidly internationalised, showing the power of new media (www.politicalecology.org). In Europe, the European Union has funded political ecology networks and doctoral student activities. These include a Political Ecology training network, largely for PhD students, called ENTITLE (http://www.politicalecology.eu), coordinated by the Autonomous University of Barcelona (AUB). It involves eight universities, NGOs and an environmental consultancy. PhD students can undertake secondments to EJOs (environmental justice organizations). Meanwhile, EJOLT, which is also based the AUB, is a global research project cataloguing, mapping and analyzing 'ecological distribution conflicts' and environmental injustice (http://www.ejolt.org). In Latin America, scholars have built on CLACSO while linking to ENTITLE; the first Latin American Conference on Political Ecology was held at the University of Santiago in Chile in October 2014.

This growth of innovative scholarship, centres and networks in political ecology is encouraging, even though it has occurred against the backdrop of the broader academic changes noted above. It is indeed somewhat ironic that the rapid growth of the field has occurred in the context of the increasingly market-driven forces in academic institutions that I have described. Whether this trend can continue, or will sooner or later hit a 'market saturation' point, is unclear but the demand from students reflecting political ecology concerns will surely shape how and where the academic field develops in the years ahead.

\section{Publishing outlets}

A publishing frenzy in the field has been driven by growth in the political ecology community, technological advances enabling faster writing, graphics, mapping and publication, as well as university 'publish or perish' drivers that measure and compare scholars in terms of quality and quantity of outputs. Books have regularly appeared in university presses and the major commercial publishers since the 1990s. This suggests that there is a market, whether through print or e-book media.

Similarly, academic journals have been a fertile ground for scholars. Of particular importance are three dedicated journals: the Journal of Political Ecology (JPE), Écologie et Politique, and Ecología Politíca. Broadbased journals where significant work in the field is published have included: Capitalism, Nature, Socialism; Conservation \& Society; Economic Geography; Human Organization; Society and Natural Resources; Progress in Human Geography; and Geoforum; occasionally too in Annals of the AAG; Antipode; Development and Change; Human Geography; Political Geography and several other, mainly US based, anthropology and international studies journals. Figure 1 gives some sense of this publication process in that it calculates the number of articles published each year between 1999 and late 2014 in which 'political ecology' appears in the 
title, keywords and abstract. This is an underestimation of actual journal article output, because the database used does not include all journals.

\section{***add Figure 1 here}

My own involvement has been as co-editor of Journal of Political Ecology since 2003, processing almost 100 articles in this period. The case of JPE is illustrative of authorship trends in the field. Back in the early 1990s, two anthropologists at the University of Arizona, Jim Greenberg and Tad Park, obtained some funding to establish JPE as an online entity, soon after internet connections began to appear on American campuses. As one of the oldest open-access journals in the social sciences, and operating in three languages (English, Spanish, French), JPE now publishes over 30 papers a year and is cited thousands of times. It remains free online, has no commercial publisher, and relies on volunteer labour. Since almost all political ecology research, including that which is opposed to injustice, is published by major corporate publishers, the JPE is unusual.

The Journal is useful for charting trends in political ecology. Initially there was an attachment to the ideas of the American anthropologist Eric Wolf, who offered a Marxist account of the transition from feudalism to industrial capitalism (Wolf, 1982). Scholars like Greenberg and Park were inspired by this, feeling that political ecology ought to amalgamate two important bodies of knowledge in relation to exploitation of the natural world - political economy, with 'its insistence on the need to link the distribution of power with productive activity' and '...ecological analysis with its broader vision of bio-environmental relationships' (Greenberg and Park, 1994: 1). They argued in JPE's opening paper that '...political ecology ... must begin not with abstract premises or dogmas, but with the productive activities of real individuals' (Ibid).

Robert Netting is cited as another important forbear. Netting's work (labelled cultural ecology) included deep historical analysis when examining agricultural societies in West Africa and Switzerland. Other influences included Meredeth Turshen's The Political Ecology of Disease (1984) that showed how health status connects to the division of labour and certain forms of class struggle. Work by dependency theorists, including Andre Gunder Frank (1969) and Immanuel Wallerstein (1974) also appealed to the Arizona political ecologists. But as Wolf (1982) observed, dependency theory could efface important differences between mercantile trade, capitalist modes of production, and the assimilation of other forms of production into capitalism. On the ecological side, meanwhile, the challenge was to link new developments in ecological theory to political economy and historically-based materialist analysis. Nonetheless, the aim was not to be dogmatic: ' ...we feel it would be ill advised to define "political ecology”, and maintain rather that all legitimate forms of political ecology will have some family resemblances but need not share a common core' (Greenberg and Park, 1994:8).

This was quite fortunate, since in the 147 articles published in the journal to October 2014, the one thing that is lacking is a common definition of political ecology, let alone a standardized methodology. Instead, authors have searched far and wide to find inspiration in different intellectual traditions ranging from the materialist work of Piers Blaikie, to post-structural approaches focusing on discourses, identities and cultures (Escobar, 2008; Robbins, 2004). The current editors (Casey Walsh and I) do insist on situating articles in some variant of political ecology, to impart intellectual coherence to the Journal.

Let me turn briefly to the sorts of topics that have featured over the years. The number of submissions has climbed, especially since the late 2000s, reflective of a wider scholarly interest in the field. Dominant themes have been the political ecology of agrarian change/agricultural issues, conservation, fishing and aquaculture, and mining (Figure 2). There is still a prevalence of papers dealing with North, Central and South America (reflecting the longstanding Arizona base of JPE), although this is weakening as more is published (Figure 3). Recent special sections have included 'Non-capitalist political ecologies', edited by Brian Burke and Boone Shear; 'Energy, environment, engagement: encounters with hydraulic fracking', edited by Anna Willow and Sara Wylie, and 'Ecologies of Hope', edited by Ravi Rajan and Colin Duncan.

\section{***add Figure 2 here}

\section{***add Figure 3 here}

\section{Pedagogy}

Since most political ecology activity remains centred on universities, teaching is vital to its perpetuation. There is a paradox here. The same cost-cutting exercises in universities described above have led to a downturn or cancellation of some critical classes in favour of those 'more useful' to students seeking practical skills necessary for work opportunities. ${ }^{3}$ But at the same time, the sheer popularity of critical environmental perspectives (including political ecology) with students has meant that university leaders and managers see the 
bottom line - they support some teaching in this field for its much-needed student numbers and, in some cases, fee income.

Political ecology now features in an array of undergraduate and postgraduate classes taught in diverse disciplinary and inter-disciplinary homes including geography, anthropology, sociology, politics, development studies and environmental studies. In the undergraduate curriculum, classes commonly include 'political ecology', 'environment and development' or 'environmental politics' in the title, with most of them assuming a basic understanding of natural resource access and international development questions. A quick internet search reveals many such classes with a heavy concentration in the US, Canada, the UK and the Antipodes, but with English and foreign language versions in Europe and beyond (e.g. Brazil, Chile, Singapore). These classes are usually optional. This situation underscores the marginal status of political ecology in the modern (Western) academy insofar as the field is not deemed to be essential. But it also means that students enrol in political ecology classes voluntarily (which may sometimes relate to their subsequent career choices). While detailed surveys have not been done, my own experience is that political ecology students aspire to change and/or to be changed; they are dissatisfied with the predominant politico-economic and environmental management narratives of the day, and want to understand different resource struggles and potential responses to them, perhaps with an eye to allying with or joining campaigns or movements (Kepe et al., 2008). Mainstream academic fields do not fill this gap in the university 'market' quite so readily.

It is at the postgraduate level that political ecology thrives. This has certainly been my experience. I started teaching political ecology in 1997 with Tony Bebbington in a Masters class at the University of Colorado. Initial numbers were very small (four students, three of whom went on to become academics: Jeffrey Bury, Brian King and Elizabeth Olsen). Subsequently, I have taught the subject at diverse universities in Europe and the US (e.g. the London School of Economics, Oxford, Arizona, Roskilde) where the desire of the students to learn about political ecology was usually matched by a wish to continue this type of work after graduation, in the workplace or through some form of advocacy or activism. Students that I have taught have found work in diverse areas including the United Nations and international development, humanitarian and environmental NGOs, in publishing firms, local government, as well as in the social responsibility and environmental appraisal units of large corporations, and in start-up companies concerned with such things as carbon management, the green economy, ecotourism and eco-planning. Based in Australia today, I regularly teach over 60 students in a postgraduate political ecology class, with several later embarking on PhDs around the world. Given its interdisciplinary appeal, my class draws in students majoring in such fields as Urban Planning, Development Studies and Public Policy where career paths may be more obvious, but still the students are attracted to more critical perspectives. International students often return to their home countries dismayed, but more knowledgeable about, the political and ecological implications of the neoliberal situations they find there - and they are keen to find a way to promote change conducive to social and environmental justice.

The pedagogy of political ecology is also shaped by the complex career paths and life-stages of those who teach. The chance to teach in this field is relatively rare, despite the popularity of political ecology among students. Hence only a few academic job advertisements specify the ability to teach it, and this may come only with greater seniority. Mid-to-late career academics may be more knowledgeable, but they can be just as angry about injustice as the (usually) younger students they teach. Others are just keen to pass on their research techniques and findings.

Perhaps the greatest constraint to good teaching is that, except if tenured, an individual (however senior and respected) can lose their job by failing to simultaneously produce research inputs and outputs like grants, publications and research students. This situation again reflects market forces; 'scholarship', for the purposes of rankings and excellence, is largely about research and far less about teaching or 'practicallyfocused' work. Concurrently, it creates a tension within the university world (less so in colleges that have a teaching mission) in which ritualistic extolling of the value that institutions place on the student, and teaching, is offset by the de facto privileging of a research-led agenda for its academic staff.

\section{Engagement}

While centred on the world of higher education and the university, political ecology has never been reducible to it. There are myriad networks and institutions in civil society that encompass such things as the everyday actions of social and environmental movements (including more radical NGOs, such as Global Witness and La Via Campesina), as well as campaigns for environmental justice. There has been an elaboration of key ideas outside the university (Martinez-Alier et al., 2014). There are also activist-writers whose activity is mostly or entirely beyond the academy, and whose publications are de facto political ecology. These include the investigative journalists and authors -George Monbiot (UK), Ann Danaiya-Usher (Norway/Thailand), Marites Dañguilan Vitug (Philippines), Naomi Klein (Canada) and Larry Lohmann (UK).

The work of a wider community keeps academic political ecologists on their toes. Already impelled forward by their students, as well as by personal conscience, the felt need to 'be useful' looms large for 
academics whether or not their institutional home promotes an applied 'engagement' mission or is even accepting of radical voices. 'Explanation' is a necessary, but not sufficient component of academic life (Batterbury and Horowitz, forthcoming). The role of the 'analytical critic', which many of us adopt, works best when it at least provides some tractable alternative proposals to the environmental and social problems that our research uncovers. Yet the problem for academics is finding ways to move forward - from complex explanations towards solving complex problems, be it through advocacy, applied research or policy advice (Bryant and Bailey, 1997; Blaikie and Muldavin, this volume). Burawoy (2005) for instance argues that academic labour places discovery and experimentation above utility or social relevance; he recommends four paths to making social science relevant, termed professional, critical, policy and public. The latter two elude many scholars. Robbins (2004) makes another distinction: political ecology can be used as 'hatchet' and 'seed': the 'hatchet' is incisive critique and a search for causation, and the 'seed' offers fresh and useful ideas, also including critique, that can feed through into direct advocacy and activism (see also Batterbury and Horowitz, forthcoming).

Debate over 'relevance' is fierce. Noteworthy here is the question of what kind of engagement to pursue (to seed or to plant?). For some, cooperating with powerful institutions through policy advice or advocacy is off the agenda; engagement should be with 'alternative' movements that seek to assert their rights and thereby subvert the powerful. For example, Arturo Escobar is renowned for critiquing mainstream development thinking and the international development sector. He has nurtured a longstanding research and activist connection to Afro-Colombian movements battling to establish an alternative way of life and territoriality beyond capitalism (Escobar, 2008). Meanwhile, Lucy Jarosz (2011), based at the University of Washington, has long promoted a local activist agenda based on a feminist care ethic and alternative agricultural production.

Other scholars believe that strategic cooperation with selected development institutions is required in order to sway their path. For example, Ed Carr (2011) pursues research in West Africa that is partly linked to USAID programs, while long ago Tony Bebbington and Judith Carney (1990) advocated working with International Agricultural Research Centres, and Bebbington worked at the World Bank on several projects. Indeed, political ecologists have been employed in such agencies as the UK's Department for International Development, and diverse Scandinavian aid agencies (Bebbington and Carney, 1990; Batterbury and Horowitz, forthcoming). Piers Blaikie, based at the University of East Anglia, held an academic post where a percentage of his work was conducted as a consultant, the majority of which was with development agencies. He combined being a political ecologist with a clear bent towards policy advice (Blaikie and Muldavin, this volume). Policy think-tanks have hosted political ecologists: the World Resources Institute (Jesse Ribot), the UK based International Institute for Environment and Development (where John Thompson, Jules Pretty, Tony Bebbington and Ian Scoones worked; see Batterbury, 2004) and the Overseas Development Institute (Tony Bebbington). Also in the UK, Larry Lohmann, Nicholas Hildyard and Sarah Sexton are based at the not-forprofit company The Corner House (www.thecornerhouse.org.uk), while the Transnational Institute (TNI, http://www.tni.org), formed in the US, is an important network of activist-scholars spanning the globe. The Centre for Science and Environment in Delhi directed by Sunita Narain, has undertaken applied varieties of political ecology work. Finally, many scholars will use opportunities that present themselves to share research findings with relevant official bodies or programmes (as I did with one German-funded development project in Burkina Faso in the 1990s, see Batterbury, 1998). In short, political ecology can be policy-relevant, helping to detour and shape the agendas of powerful institutions.

In diverse ways therefore, political ecologists can often demonstrate the feasibility of engagement. The point in doing so is not to abandon one's critical faculties, but to deploy them (Olivier de Sardan, 1995). All manner of involvement is possible: notably in organizations that are conserving natural resources, tackling persistent poverty, and fighting for environmental justice (Martinez-Alier et al., 2014).

\section{Conclusion}

I have argued that political ecology is a research field with many personal and political dimensions. Deliberately conceived as a multi-disciplinary enterprise, it is found in the scholarship of individuals that often transgress the quotidian hierarchies and structures of universities and academic disciplines. Its key findings transcend the social and natural sciences, while zeroing in on social and ecological injustices: for example, evictions resulting from protected area management and land grabbing.

Political ecology is broad in scope. There are no university departments of political ecology with core funding and a legacy of staff and PhD students to sustain them; instead there are clusters and individuals scattered across the world. Research output is plentiful, widely read and published in a range of outlets, but so far it has lacked a natural centre of gravity (although the non-commercial Journal of Political Ecology may be starting to fill this gap). It has not always directly penetrated mainstream thinking on environmental issues, including the 'human dimensions of global environmental change', despite the complex and cutting explanations offered by its practitioners (Castree et al., 2014: 763). Teaching is largely conducted as ‘bolt-on’ classes in 
existing programs, with 'optional' status in courses. But these classes are proving increasingly popular with students and contribute to a burning sense of injustice, as well as a desire to right at least some of the wrongs of untrammelled greed and inequality in the world.

Given that it is a field fighting against the very strong neoliberal current of our times, it is only to be expected that political ecology will remain a marginal part of the academy in the short and medium term (despite its increasing prominence in human geography and anthropology). This is also true outside western academic institutions. While it might be rooted in different national and regional academic cultures (as this International Handbook explores), the general consensus is that political ecology must address and fight political, economic, social and ecological inequities. This means that it will never be popular with universities that are fully beholden to political and economic power-brokers. Indeed, and as scholars join forces with political ecologists 'out there' in civil society, the stage is set for an even greater oppositional politics both inside and beyond the academy (e.g. Willow and Wylie, 2014). Political ecologists will not shy away from such confrontation as they join wider struggles that seek to 'speak truth to power', attempting thereby to influence policies, organisations and practices. This task will not be easy, but then they have known that all along.

\section{Notes}

1) I wish to thank Bram Büscher, Wolf Dressler, Christian Kull, Eric Perramond and Priya Rangan for helpful suggestions.

2) This is not an exclusive list of key individuals and institutions, and it is a snapshot as of late 2014. Of course, many political ecologists work outside such groupings.

3) I will not list these, but there are also newly established ones, for example at SOAS, University of London.

\section{References}

Adkin, L. (ed.) (forthcoming), First World Petro-Politics, Toronto: University of Toronto Press.

Agrawal, A. (2005), Environmentality, Durham, NC: Duke University Press.

Alimonda, H. (ed.) (2002), Ecología política [Political ecology], Buenos Aires: CLACSO.

Amanor, K.S. (1994), The New Frontier, London: Zed.

Bassett, T.J. (1988), 'The Political Ecology of Peasant-Herder Conflicts in the Northern Ivory Coast', Annals of the Association of American Geographers, 78, 453-72.

Bassett, T. and D.E. Crummey (eds) (1993), Land in African Agrarian Systems, Madison, WI: University of Wisconsin Press.

Batterbury, S.P.J. (1998), 'Local environmental management, land degradation and the 'Gestion des Terroirs' approach in West Africa; policies and pitfalls’, Journal of International Development, 10, 871-98.

Batterbury, S.P.J. (2004), 'The International Institute for Environment and Development: notes on a small office’, Global Environmental Change, 14, 367-71.

Batterbury, S.P.J. (2008a), 'Tenure or permanent contracts in North American higher education? A critical assessment', Policy Futures in Education, 6, 286-97.

Batterbury, S.P.J. (2008b), 'Anthropology and global warming: the need for environmental engagement', The Australian Journal of Anthropology, 19, 62-7.

Batterbury, S.P.J. (2013), 'Who are the radical academics today?' Available at: http://simonbatterbury.wordpress.com/2013/03/01/where-have-the-radical-scholars-gone/ [Accessed: 5 July 2014].

Batterbury, S.P.J. and L.S. Horowitz (eds) (Forthcoming), Engaged Political Ecology, Cambridge: Open Book Publishers.

Bebbington, A.J and J. Carney (1990), 'Geographers in the International Agricultural Research Centers: theoretical and practical considerations', Annals of the Association of American Geographers, 80, 34-48. 
Bebbington, A.J., M.P. Connarty, W. Coxshall, H. O'Shaughnessy and M. Williams (2007), Mining and Development in Peru, London; Peru Support Group.

Bebbington A.J. and J. Bury (eds) (2013), Subterranean Struggles, Austin, TX: University of Texas Press.

Berry, S. (1993), No Condition is Permanent, Madison, WI: University of Wisconsin Press.

Blaikie, P. (1985), The Political Economy of Soil Erosion in Developing Countries, London: Longman.

Blaikie, P. (1989a), 'Environment and Access to Resources in Africa’, Africa, 59, 18-40.

Blaikie, P. (1989b), 'Explanation and Policy in Land Degradation and Rehabilitation for Developing Countries', Land Degradation \& Rehabilitation, 1, 23-37.

Blaikie, P. (1991), 'Decentralization and Participation in Soil and Water Conservation: New Opportunities and New Problems’, ITC Journal, 4, 281-5.

Blaikie, P. and H.C. Brookfield (eds) (1987), Land Degradation and Society, London: Methuen.

Blaikie, P. and J. Muldavin (this volume), 'Building a policy reform dossier', in R.L. Bryant (ed.), International Handbook of Political Ecology, Cheltenham, UK: Edward Elgar.

Bond, P. (2012), 'The Right to the city and the eco-social commoning of water: discursive and political lessons from South Africa’, in F. Sultana and A. Loftus (eds), The Right to Water, London: Earthscan, pp. 190-205.

Bryant, R.L. (1992), 'Political ecology: an emerging research agenda in Third-World studies', Political Geography, 11, 12-36.

Bryant, R.L. and S. Bailey (1997), Third World Political Ecology, London: Routledge.

Bryant, R.L and M.K. Goodman (2004) 'Consuming narratives: the political ecology of "alternative” consumption', Transactions of the Institute of British Geographers, 29, 344-66.

Burawoy, M. (2005), ‘For public sociology’, American Sociological Review, 70, 4-28.

Carr, E.R. (2011), 'If you are uncomfortable, you are probably doing it right', Environment and Planning A, 43, 2797-2800.

Castree, N., W.M. Adams, J.Barry, B. Büscher, D. Demeritt, R. Duffy, U. Felt, K. Neves, P. Newell, L. Pellizzoni, K. Rigby, P. Robbins, L. Robin, D. Bird Rose, A. Ross, D. Schlosberg, S. Sörlin, P. West, M. Whitehead and B. Wynne (2014), 'Changing the intellectual climate', Nature Climate Change, 4, 763-8.

Chartier, D. and M. Löwy (2013), ‘L’amérique latine: terre de luttes socioécologiques’ [Latin America: socioecological battleground], Ecologie \& Politique, 46, 13-20.

Davies S. (1996), Adaptable Livelihoods, Chichester, UK: Wiley.

Doolittle, A. (this volume), 'The best of many worlds: methodological pluralism in political ecology', in R.L. Bryant (ed.), International Handbook of Political Ecology, Cheltenham, UK: Edward Elgar.

Durand Smith, L., F. Figueroa Díaz and M. Genet Guzmán Chávez (2011), 'La ecología política en México ¿Dónde estamos y para dónde vamos?’ [Political ecology in Mexico: where are we and where are we heading to?], Estudios sociales [Social Studies], 19, 281-307.

Enzenberger, H.M. (1974), ‘A Critique of Political Ecology’, New Left Review, 84, 3-31.

Escobar, A. (2008), Territories of difference, Durham, NC: Duke University Press.

Freitas, T.A.M. and A.C.S. Mozine (this volume), 'Towards a Lusophone political ecology: assessing 'para ingles ver' environments’, in R.L. Bryant (ed.), International Handbook of Political Ecology, Cheltenham, UK: Edward Elgar. 
Gadgil, M. and R. Guha (1992), This Fissured Land, Delhi: Oxford University Press.

Gautier D. and T.A. Benjaminsen (eds) (2012), Environnement, discours et pouvoir [Environment, discourse and power], Paris: Editions Quae.

Gray, L. and B. Dowd-Uribe (2013), 'A political ecology of socio-economic differentiation: debt, inputs and liberalization reforms in southwestern Burkina Faso', Journal of Peasant Studies, 40, 683-702.

Greenberg, J.B. and T.K. Park (1994), ‘Political ecology’, Journal of Political Ecology, 1, 1-12.

Gunder Frank, A. (1966), The Development of Underdevelopment, New York: Monthly Review.

Jarosz, L. (2011), 'Nourishing women: toward a feminist political ecology of community supported agriculture in the United States', Gender, Place and Culture, 18, 307-26.

Kepe, T., J.-F. Bissonnette and D.J. Roberts (2008), 'Why are students attracted to political ecology?' Environment and Planning A, 40, 2539-43.

Kim, S., G. Ojo, R.Z. Zaidi and R.L. Bryant (eds) (2012), 'Other political ecologies', Singapore Journal of Tropical Geography, 33, 29-123.

Koensler, A. and C. Papa (2013), 'Introduction: beyond anthropocentrism, changing practices and the politics of "nature”', Journal of Political Ecology, 20, 286-94.

Lawhon, M., H. Ernstson and J. Silver (2014), 'Provincialising urban political ecology: towards a situated UPE through African urbanism’, Antipode, 46, 497-516.

Lee, S. (this volume), 'Benefit sharing in environmental governance: beyond hydropower in the Mekong River Basin’, in R.L. Bryant (ed.), International Handbook of Political Ecology, Cheltenham, UK: Edward Elgar.

Martin F. and R. Larsimont (2014), ‘L’écologie politique depuis l’Amérique Latine’ [Political ecology from Latin America], in Actes du premier colloque sur Penser l'écologie politique: Sciences sociales et interdisciplinarité, Paris, 13-14 January ; http://events.it-sudparis.eu/ecologiepolitique/rub2/Actes.pdf

Martinez-Alier J., I. Anguelovski, P. Bond, D. Del Bene, F. Demaria, J-F. Gerber, L. Greyl, W. Haas, H. Healy, V. Marín-Burgos, G. Ojo, M. Porto, L. Rijnhout, B. Rodríguez-Labajos, J. Spangenberg, L. Temper, R. Warlenius and I. Yánez (2014), 'Between activism and science: grassroots concepts for sustainability coined by Environmental Justice Organizations’, Journal of Political Ecology, 21, 19-60.

McMichael, P. (2014), 'Rethinking land grab ontology', Rural Sociology, 79, 34-55.

Molle, F. ,T. Foran and M. Kakonen (eds) (2009), Contested Waterscapes in the Mekong Region, London: Earthscan.

Olivier de Sardan, J.-P. (1984), Les sociétés songhay-zarma [Songhay-Zarma society], Paris: Karthala.

Olivier de Sardan, J.-P. (1995), Anthropologie et développement [Anthropology and development], Paris: Karthala.

Pandey, R. (2013), 'Development and Environment: An Assessment of Population Growth vis-à-vis Soil Erosion in Nepal', Dhaulagiri Journal of Sociology and Anthropology, 7, 173-96.

Peet R. and M.J. Watts (1996), 'Liberation ecology: development, sustainability, and environment in an age of market triumphalism’, in R. Peet and M.J. Watts (eds), Liberation Ecologies, London: Routledge, pp. 1-45.

Peluso, N.L. (1992), Rich forests, poor people, Berkeley, CA: University of California Press.

Perramond, E. (2007), ‘Tactics and strategies in political ecology research', Area, 39, 499-507. 
Robbins, P. (2004), Political Ecology, Oxford: Blackwell.

Rocheleau, D and D. Edmunds (1997), 'Women, Men and Trees: Gender, power and property in forest and agrarian landscapes', World Development, 25, 1351-71.

Rocheleau, D., B. Thomas-Slayter and E. Wangari (eds) (1996), Feminist Political Ecology, London: Routledge.

Schroeder, R.A. (1997), "Reclaiming" Land in the Gambia: Gendered Property Rights and Environmental Intervention', Annals of the Association of American Geographers, 87, 487-508.

Scott, J.C. (1985), Weapons of the Weak, New Haven, CT: Yale University Press.

Schneider, F., G. Kallis and J. Martinez-Alier (2010), 'Crisis or opportunity? Economic degrowth for social equity and ecological sustainability’, Journal of Cleaner Production, 18, 511-8.

Somma, M. (1993), ‘Theory Building in Political Ecology’, Social Science Information, 32, 371-85.

Tschakert, P. (2013), 'From impacts to embodied experiences: Tracing political ecology in climate change research', Danish Journal of Geography, 112, 144-58.

Tuk-Po, L., W. de Jong and A. Ken-ichi (eds) (2003), The political ecology of tropical forests in Southeast Asia, Kyoto: Kyoto University Press.

Turner, M. (this volume), 'Integrating politics and ecology through mixed methods', in R.L. Bryant (ed.), International Handbook of Political Ecology, Cheltenham, UK: Edward Elgar.

Turshen, M. (1984), The Political Ecology of Disease in Tanzania, New Brunswick, NJ: Rutgers University Press.

Vaccaro I., O. Beltran and P.A. Paquet (2013), 'Political ecology and conservation policies: some theoretical genealogies’, Journal of Political Ecology, 20, 255-72.

van der Ploeg, J.D. and N. Long (1994), 'Heterogeneity, Actor and Structure: towards a reconstitution of the concept of structure’, in D. Booth (ed.), Rethinking Social Development, London: Longman, pp. 60-90.

Wallerstein, I. (1974), The Modern World-System, vol. I, New York: Academic Press.

Willow, A. and S. Wylie (2014), 'Politics, ecology, and the new anthropology of energy: exploring the emerging frontiers of hydraulic fracking', Journal of Political Ecology, 21, 222-36.

Wisner, B. (1993), 'Geographical vulnerability: geographical scale and existential reality’, in H.G. Bohle (ed.), Worlds of Pain and Hunger, Saarbrucken: Verlag Breitenbach, pp. 13-52.

Wisner, B., P. Blaikie, T. Cannon and I. Davis (2004), At Risk, $2^{\text {nd }}$ edition, London: Routledge.

Wolf, E. (1982), Europe and the People without History, Berkeley, CA: University of California Press.

Wynberg, R.P. and D. Fig (2014), 'Realising environmental rights: civic action, leverage and litigation', in M. Langford, B. Cousins, J. Dugard and T. Madlingozi (eds), Socio-Economic Rights in South Africa, New York: Cambridge University Press. pp. 310-40.

Yeh, E.T. (this volume), 'Political ecology in and of China', in R.L. Bryant (ed.), International Handbook of Political Ecology, Cheltenham, UK: Edward Elgar. 


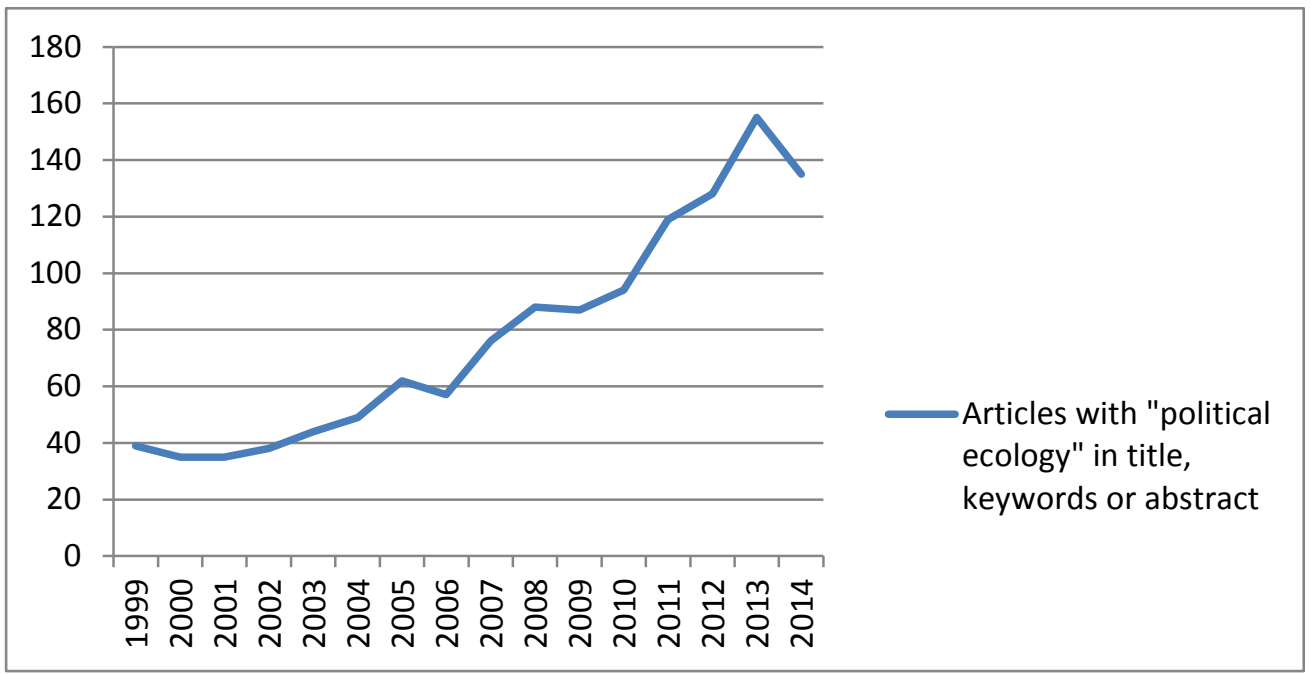

Figure 1: Growth in political ecology articles referenced in Scopus, 1999-Oct. 2014. Many journals are not yet included in Scopus, and the Journal of Political Ecology was only counted after 2011. Source: Scopus

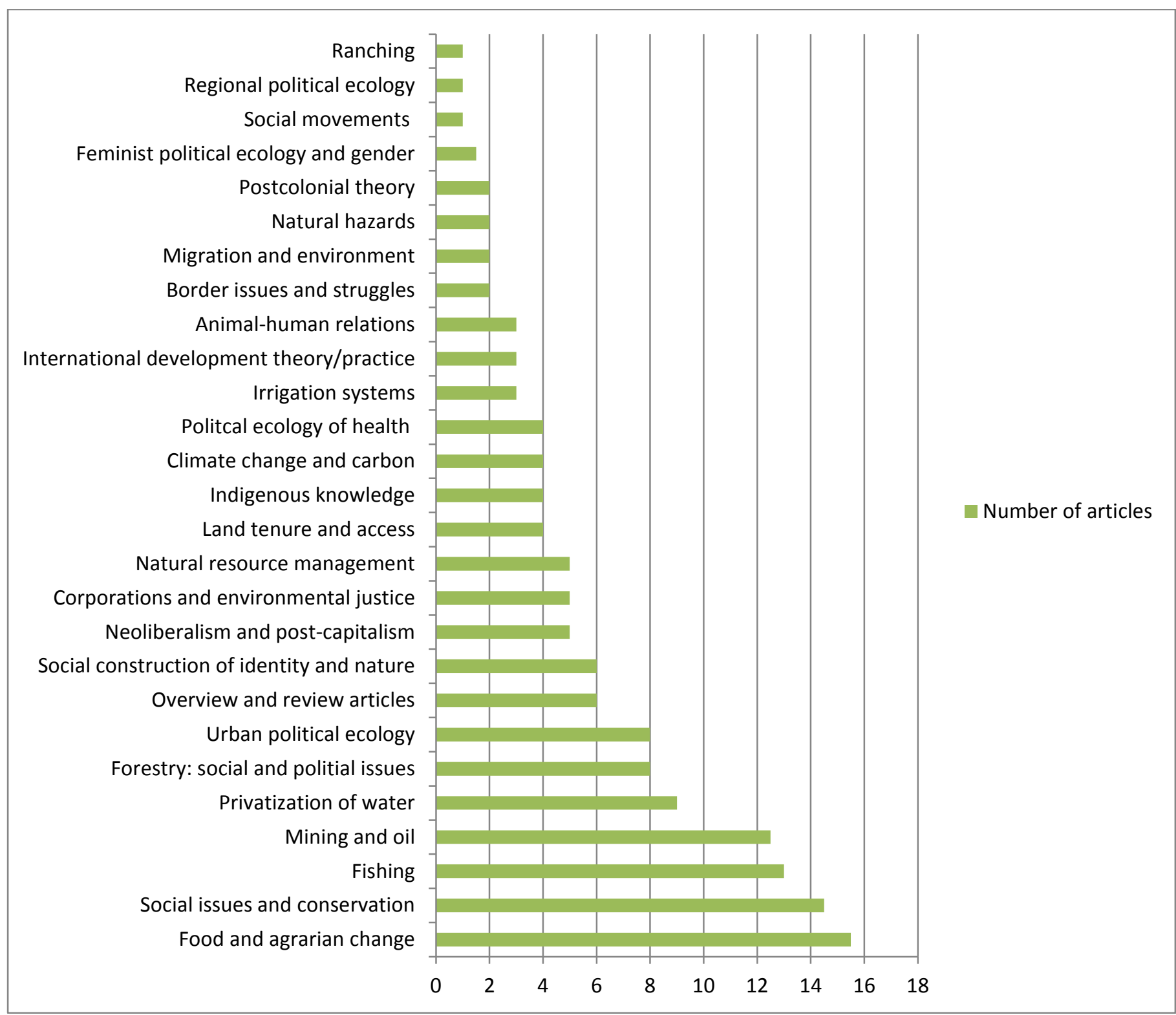


Figure 2: Articles published in the Journal of Political Ecology 1994-2014 (October), by main theme. N=145.

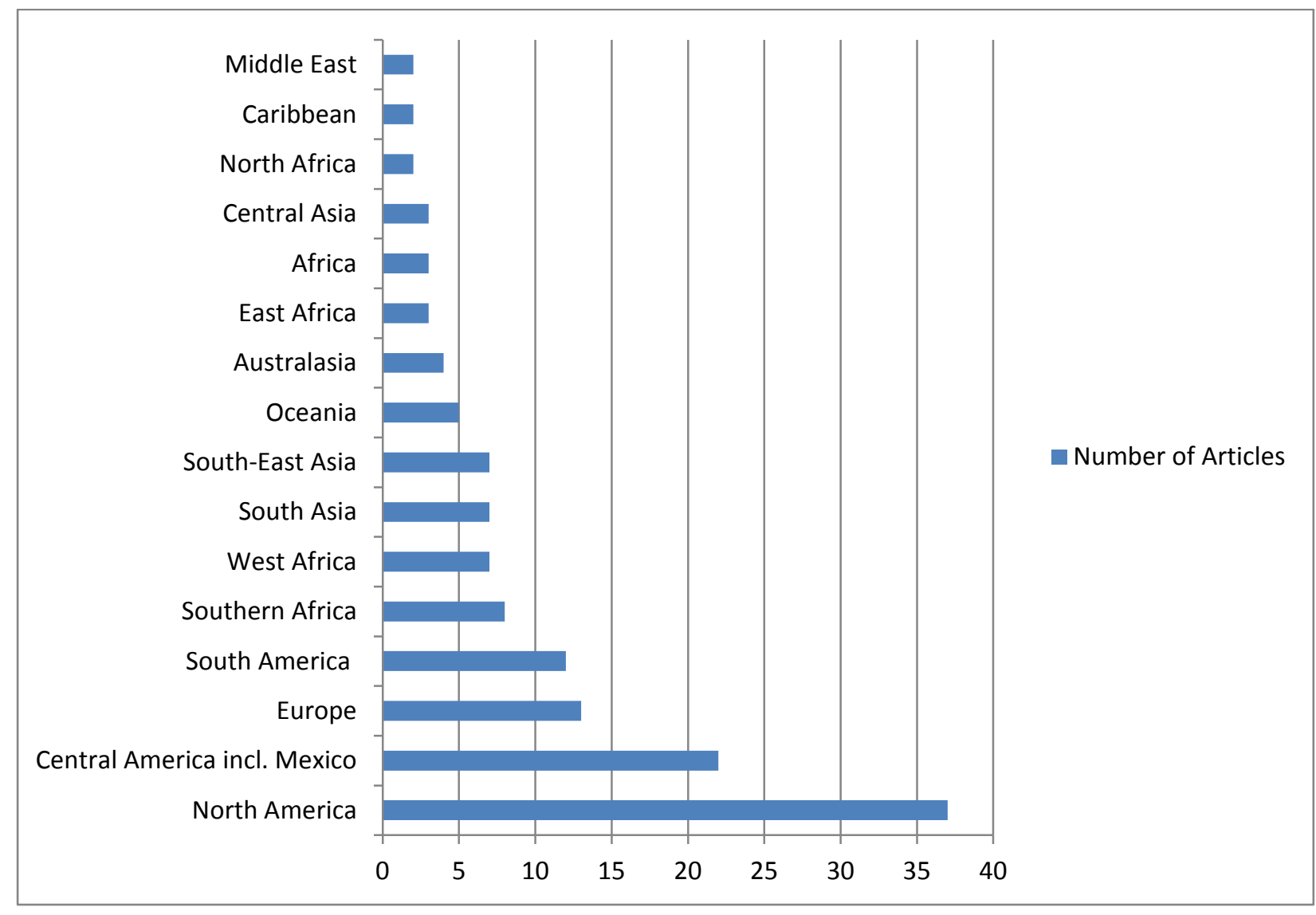

Figure 3: Regional focus of articles published in the Journal of Political Ecology 1994- October 2014. N=137. 